\title{
Nausea and Space in Sartre's La Nausée and Céline's Voyage au bout de la nuit
}

\author{
Paul B. Kelley \\ (Columbia University)
}

In La poétique de l'espace, Gaston Bachelard envisions fictional space in terms of an exploration of the specific reality constitutive of the poetic image - a topophilia whose principal attraction lies in its vigorous phenomenological approach to the literary imagination. 1 Following in Bachelard's footsteps, this essay seeks to compare the novelistic space of Sartre's La nausée with Céline's Voyage au bout de la nuit. This entails a re-examination of the Sartrean notion of nausea which, as Jean-Pierre Richard's 1973 essay intitled La nausée de Céline clearly attests, has become more or less a cliché in the critical discourse dealing with Voyage au bout de la nuit. ${ }^{2}$ Through an assimilation of the question of nausea with that of space, we hope to re- evaluate the two novels from the angle of their mutual differences rather than in terms of their superficial similarities. In an effort to reconstitute the space of nausea in its full philosophical dimensions, we shall preface our findings by contrasting the Sartrean model with some remarks from that other great French phenomenologist of the entre-deuxguerres, Maurice Merleau-Ponty.

Since it is virtually impossible to speak of nausea in Céline without evoking the spectre of Sartrean existentialism, ${ }^{3}$ let us first return to the source of its definition in L'être et le néant. ${ }^{4}$

L'affectivité coenesthésique est alors pure saisie non-positionnelle d'une contingence sans couleur, pure appréhension de soi comme existence de fait. Cette saisie perpétuelle par mon pour-soi d'un goût fade et sans distance qui m'accompagne jusque dans mes efforts pour m'en délivrer et qui est mon goût, c'est ce que nous avons déjà écrit ailleurs 
sous le nom de Nausée. Une nausée discrète et insurmontable révèle perpétuellement mon corps à ma conscience: il peut arriver que nous recherchions l'agréable ou la douleur physique pour nous en délivrer, mais dès que la douleur ou l'agréable sont existés par la conscience, ils manifestent à leur tour sa facticité et sa contingence et c'est sur fond de nausée qu'ils se dévoilent. Loin que nous devions comprendre ce terme de nausée comme une métaphore tirée de nos écoeurements physiologiques, c'est au contraire, sur son fondement que se produisent toutes les nausées concrètes et empiriques (nausées devant la viande pourrie, le sang frais, les excréments, etc.) qui nous conduisent au vomissement. (404)

[Coenesthetic affectivity is then a pure, non-positional apprehension of a contingency without color, a pure apprehension of the self as a factual existence. This perpetual apprehension on the part of my for-itself of an insipid taste which I cannot place, which accompanies me even in my efforts to get away from it, and which is my taste - this is what we have described elsewhere under the name of Nausea. A discrete and insuperable nausea perpetually reveals my body to my consciousness. Sometimes we may look for the pleasant or for physical pain to free ourselves from this nausea; but as soon as the pain and the pleasure are existed by consciousness, they in turn manifest its facticity and its contingency; and it is on the ground of this nausea that they are revealed. We must not take the term nausea as a metaphor derived from our physiological disgust. On the contrary, we must realize that it is on the foundation of this nausea that all concrete and empirical nauseas (nausea caused by spoiled meat, fresh blood, excrement, etc.) are produced and make us vomit.]

As the explicit reference to the novel illustrates, nausea constitutes in the philosophy of Sartre what Simone de Beauvoir has described as a metaphysical truth expressed in a literary form. ${ }^{5}$ This observation is further reinforced by a symptomatic reading of the novel as a bringing into play of theoretical elements of the author's philosophical thought. As one critic has demonstrated, the interiorization which follows the uncovering of facticity and which leads to the powerlessness and disgust characteristic of nausea is in fact overdetermined by an essential element of Sartre's ontology: the universality of pre-reflexive or non-thetic consciousness. ${ }^{6}$ It follows 
that for Sartre the experience of space is always linked to the revelation of the oppositional relation between consciousness (pour-soi) and the disclosure of its facticity in the world (en-soi). The objectivation of consciousness in the form of contingency is thus the paradoxical result of the aspiration for a radical interiorization towards the nothingness of pure consciousness. Likewise, pure or coenesthetic affectivity accompanying the original experience of this contingency constitutes the ultimate outcome of its reflexion via consciousness.

The body in Sartre is thus revealed phenomenologically as the passive milieu in which the existential relationship between consciousness and the world materializes against the dull but ever-present background of nausea. However, in Merleau-Ponty's Phénoménologie de la perception we find an altogether different conception of the body and thus, of its relation to space. According to Merleau-Ponty, corporeity constitutes the sole means of comprehending space insofar as the subject-world relation is to be understood above all as an organic relation: the subject's hold over his world is therefore the origin of its spatiality. The existential body is further described in the famous chapter on space as labyrinthine, indeed mysterious, as it contains the constituent parts of space "enveloped" ["enveloppées"] within its unique hold on the world (318). As regards nausea, it is likewise described in terms of contingency, but here it is a matter of a contingency experienced by a pre-personal subject whose communicative relationship with the world is "older than thought" ["plus vieille que la pensée"] (293-294). This primordial level of space is at the horizon of all phenomenological perception and - as opposed to the Sartrean cogito - inaccessible to our thematization (294). Consequently, nausea in Merleau-Ponty can be characterized as a "vital experience" ["une expérience vitale"] evocative of birth (294). Thus, for Merleau-Ponty the original experience of space stems from the oblivion of contingency, and the eternal renewal of this "bias in favor of being" ["ce parti-pris en faveur de l'être"] constitutes a "perpetual contribution" ["un apport perpétuel"] to the world (294).

The body must be conceived then, according to Merleau-Ponty, as the means of our communication with time as well as space. Since the body, and not consciousness, constitutes the privileged locus of our primordial affectivity in space, its "power of natural expression" ["son pouvoir d'expression naturelle"] serves, as regards memory, to "re-open time through the implications of the present" ["rouvrir le temps par les implications du présent"] (211). Consequently, the word as the expression of thought must not be understood as simply a manner of designating an object of consciousness; in effect, it constitutes the presence of this thought in the sensorial world 
(212). This "excess of our existence upon natural being" ["excès de notre existence sur l'être naturel"] (226) through the incarnation of thought in the form of the word constitutes the essential means by which the body realizes its open-ended and indefinite power to signify (229), and in this manner, to transcend itself. Hence, the principal function of language in Merleau-Ponty is to project itself incessantly onward, like a wave (229). And, since according to Merleau-Ponty it is the distinctive feature of the body to actually 'become' what it signifies, the analysis of the word and of meaning reveals in exemplary fashion its enigmatic nature (230).

This exteriorization of reflexion by way of corporeity can by understood as the introduction of a third dimension to our interior experience: that of depth. Since it immediately reveals the link between the subject and space, depth is more existential than the other dimensions of space (296). Finally, it is this spatial dimension which requires us to "reject preconceived notions of the world and rediscover the wellspring of primordial experience" [“à rejeter le préjugé du monde et à retrouver l'expérience primordiale où il jaillit"] (296). According to Merleau-Ponty, the classic expression of this return to the source of our experience is found in the form of the myth. That is, myth, similar to the poetic image - and it is at this moment that we evoke the study by Bachelard alluded to at the beginning of this essay — encloses a meaning [sens] which is not notional but rather "a direction of our existence" ["une direction de notre existence"] (329). This idea of the subjectivity of mythical space will provide the outer framework for our comparison of Sartre's Nausée with Céline's Voyage au bout de la nuit.

Beginning then with the various accounts of nausea in the two novels we find considerable differences. In Sartre's Nausée the experience of nausea, described as this "faint happiness [...] sprawled upon the depths of our time" ["c'est un petit bonheur de Nausée: il s'étale au fond de notre temps"] (38), is presented to the reader at the outset as Roquentin's sole destiny. Thus, the successive attacks of nausea after the visit to the Bouville art museum and finally in the public gardens are endowed with an increasing significance culminating in Roquentin's resignation to stay in Bouville. Moreover, the character of Roquentin is revealed at the beginning of the novel as a jaded man who has completed his life's journeys and now must simply wait peacefully for his nausea to arrive:

Moi, j'ai eu de vraies aventures. Je n'en retrouve aucun détail, mais j'aperçois la enchaînement rigoureux des circonstances. J'ai traversé les mers, j'ai laissé des villes derrière moi et j'ai rencontré des fleuves 
ou bien je me suis enfoncé dans des forêts, et j'allais toujours vers d'autres villes. J'ai eu des femmes, je me suis battu avec des types; et jamais je ne pouvais revenir arrière, pas plus qu'un disque peut se tourner à rebours. Et tout cela me menait où? A cette minute-ci, à cette banquette, dans cette bulle de clarté toute bourdonnante de musique. (41)

[Me, I've had some real adventures. I can't recall a single detail but I do perceive the rigorous chain of circumstances. I've crossed the oceans, I've left cities behind and I've encountered rivers or else I've disappeared into forests and I was always going towards other cities. I've had women, I've fought with men; and never could I go back, no more than a record can turn backwards. And all this has got me where? To this minute, to this wall seat, in this bubble of clarity all buzzing with music.]

The inherent nostalgia of this "great feeling of adventure" ["grand sentiment d'aventure"] (81) which will arise in Roquentin on the Jetée-Promenade and which will momentarily attenuate the sensation of nausea is nonetheless ruthlessly parodied in the character of the Autodidact, who shows his unfailing admiration for Roquentin's travels while hoping to do the same after his seemingly endless studies. For Roquentin, then, "adventures are in books" ["les aventures sont dans les livres"] (59), and he can only wait for time to regain its "daily lifelessness" ["sa mollesse quotidienne"] (60) in a world in which "there are never any beginnings" ["il n'y a jamais de commencements"] (62).

In Voyage au bout de la nuit, however, the experience of nausea unfolds in an altogether different manner. First of all, the long narrative preparation found in La nausée is largely absent: nausea simply happens to Bardamu at the outset of the novel, at that precise moment in the text when, as Gilbert Schilling has remarked, he has personal vision neither of space nor of time. ${ }^{7}$ Furthermore, this true nausea which drives Bardamu to vomit and even to faint is punctuated at his return to consciousness by the sole realization that "the war was still present" ["la guerre ne passait pas"] (33). Nonetheless, as Schilling observes, it is precisely this experience which grounds the autonomy of the Célinian character ${ }^{8}$ insofar as previous to this realization, the war for Bardamu was nothing more than an "immense, universal farce" ["une immense, universelle moquerie"] (22). In short, it is owing to this unique experience that Bardamu - whose insouciance at the beginning of the novel evoked a being originally absent 
to the world and for whom the present was without meaning or direction ${ }^{9}$ - effectively discovers the full sens, in Merleau-Pontian terms, of his own situation.

This fundamental divergence regarding the experience of nausea is made manifest by the way in which these little moments of crisis are treated by the narrator. In the familiar surroundings of the Café Mably, Roquentin is led to reflect on the fact that not only is nausea inside him but also he is inside it. In contrast, upon arriving in New York Bardamu's "vertigo in reverse" ["ce vertige à l'envers"] (245) experienced amidst the strange decor reveals to him that "philosophizing is but another manner of being afraid and leads only to cowardly pretense" ["philosopher n'est qu'une autre façon d'avoir peur et ne porte guère qu'aux lâches simulacres"] (264). This resistance to theory in the proper sense of the term arises as well following the abortive meeting with Robinson during an evening in the African jungle: "It is, to be sure, sheer folly to occupy oneself with other than that which can be seen" ["Il y a, c'est exact, beaucoup de folie à s'occuper d'autre chose que de ce qu'on voit"] (221). In La nausée, Roquentin lives alone and only seeks refuge among others "in case of alert" ["en cas d'alerte"] (21). In the Voyage, Bardamu's apparent voyeurism in spying on New Yorkers' private lives stems - as the scene in the fast-food restaurant humorously attests - from a genuine desire to participate, 10 to which the narrator punningly refers in comparing the posh section of Paris to a "slice of urban cake" ["une tranche de gâteau urbaine"] while the rest is dismissed as being only "hardship and dung" ["peine et fumier"] (100). Thus, whereas Roquentin is aware that he is "a man all alone, with his only body" ["un homme tout seul, avec son seul corps"] (97) whose memories ceaselessly sift through him, Bardamu recognizes that "one is weighed down by the subject of one's life when one lives alone" ["on est accablé du sujet de sa vie quand on vit seul"] and that "being alone is to practice dying" ["être seul c'est s'entraîner à la mort"] (478). For the Sartrean narrator, the consciousness of freedom is sovereign: as Roquentin puts it, "I have only ever wanted to be free" ["je n'ai voulu qu'être libre"] (97). For the Célinian narrator, it is an acute consciousness of intersubjectivity that reigns supreme: as Bardamu says, "the main thing is that one explains oneself in life. Together we succeed better than alone" ["Le tout c'est qu'on s'explique dans la vie. A deux on y arrive mieux que tout seul"] (26).

It follows that for the Célinian character the body is above all a source of apprehension, similar to "that captive or natural spirit" ["cet esprit captif ou naturel"] Merleau-Ponty calls the lived body ["le corps propre"] (294). The body in Céline is literally "atomic torture" ["torture atomique"] (425), insofar as it conceals a labyrinthine quality which is opaque to reflexion. Roquentin, in contrast, is able to 
describe himself as being "without secret dimensions, limited to [his] body" ["sans dimensions secrètes, limité à mon corps"] (54). Indeed, In the Voyage, this subjectification of the body's space equally applies to the description of space in general. Thus, New York becomes "architectural torture" ["une torture architecturale"] (264), Broadway a "sad wound" ["une plaie triste"] (247), and Bardamu's lodging in Clichy is considered by Madame Henrouille as "a real infection" ["une vraie infection"] (321). By extension, nocturnal space is described by Bardamu as "my own night, this coffin" ["ma nuit à moi, ce cercueil"] (370), while in La nausée Bouville is simply "crushed by the night" ["écrasé par le soir"] (223), and Roquentin describes the Boulevard Noir as "inhuman" ["inhumaine"] during an evening stroll (44). As for the character of Robinson in Voyage au bout de la nuit, so often associated with the night, after his accidental blinding he is described as having reached "the end of the world" ["le bout du monde"] from whence one must come back in order to "return where all begins again" ["il faut retourner là où tout recommence"] (416). In the same vein, Bardamu poignantly describes life as "a ray of light ending in the night" ["un bout de lumière qui finit dans la nuit"] (430). Now, can we not consider the character of Robinson as a romanesque embodiment of this "blind adhesion to the world" ["cette adhésion aveugle au monde"] (294) which is no less than Merleau-Ponty's lived body [corps propre]? Bardamu's decision in Africa "to take to the forest before me in the direction that that wretched Robinson had already taken" [de prendre la forêt devant moi dans la direction qu'avait prise déjà ce Robinson de tous les malheurs"] (228), is it not motivated by the same élan vital at the heart of his own being and which inspires his journey to the end of the night? Robinson's misfortune - and therefore Bardamu's own - does it not consist in the sole fact that 'it is not perseverance that we lack, but rather being on the right path which leads to a peaceful death" ["C'est donc pas l'acharnement qui nous manque à nous non, c'est plutôt d'être dans la vraie route qui mène à la mort tranquille"] (480)?

"One must know how to get outside of Time" ["Il faut savoir sortir du temps"] (465), replies Bardamu. An impossible task to precede oneself, to be the author of one's own origin. For Roquentin, the desire is exactly the opposite: "I have wanted the moments of my life to follow one another and to order themselves like those that one recalls. One might as well attempt to catch time by the tail" ["J'ai voulu que les moments de ma vie se suivent et s'ordonnent comme ceux d'une qu'on se rappelle. Autant vaudrait tenter d'attraper le temps par la queue"] (64). Thus, for Roquentin "one must choose: live or recount" ["il faut choisir: vivre ou raconter"] (62). For Bardamu, in contrast, the silence of Parapine, his former professor, in Baryton's asylum seems at first an "ingenious way" to "escape his personal misery" ["un ingénieux 
chemin $\{\ldots\}$ pour s'évader à sa misère intime"] (536). However, it is through his own experience in the asylum that Bardamu learns otherwise:

Je me tenais au bord dangereux des fous, à leur lisière pour ainsi dire, à force d'être toujours aimable avec eux, ma nature. Je ne chavirais pas mais tout le temps, je me sentais en péril, comme s'ils m'eussent attiré sournoisement dans les quartiers de leur ville inconnue. Une ville dont les rues devenaient de plus en plus molles à mesure qu'on avançait entre leurs maisons baveuses, les fenêtres fondantes et mal closes, sur ces douteuses rumeurs. Les portes, le sol mouvants... L'envie vous prend quand même d'aller un peu plus loin pour savoir si on aura la force de retrouver sa raison, quand même, parmi les décombres. Ça tourne vite au vice la raison, comme la bonne humeur et le sommeil chez les neurasthéniques. On ne peut plus penser qu'à sa raison. Rien ne va plus. Fini de rigoler. (537-38)

[I kept to the dangerous side of madmen, at their edge as it were, by dint of always being friendly with them, my nature. I didn't founder but I constantly felt in danger, as if they might underhandedly draw me into the districts of their unknown city. A city whose roads became softer and softer as one went along among their drooling houses, with their melting windows poorly closed, upon those dubious murmurings. The unsteady ground and shaky doors... You feel like going a bit further on, just the same, in order to find out if you'll have the force to regain your sanity among the rubble. Reason turns quickly to vice, as good spirits and sleep do with neurasthenics. One can only think of one's sanity. The game is up. No more fooling around.]

Taking the route of madness is thus revealed to Bardamu as the wrong way on a quicksandy pavement and leading straight to the pitfalls of solipsism:

Un fou, ce n'est que les idées ordinaires d'un homme mais bien enfermées dans une tête. Le monde n'y passe pas à travers sa tête et ça suffit. Ça devient comme un lac sans rivière une tête fermée, une infection. (523)

[A madman is only one man's ordinary ideas, but tightly enclosed in one head, and that's enough. The world can't pass through it, and 
that's enough. It becomes like a lake without a river, a closed head, an infection.]

Hence, Bardamu evinces his unfailing admiration for human resilience or elasticity, above all in the domain of erotic space:

Sophie possédait cette démarche ailée, souple et précise qu'on trouve, si fréquente, presque habituelle chez les femmes d'Amérique, la démarche des grands êtres d'avenir que la vie porte ambitieuse et légère encore vers de nouvelles façons d'aventures... Trois-mâts d'allégresse tendre, en route pour l'Infini... (598)

[Sophie possessed this winged gait, supple and precise that one finds so often, almost habitually, in American women, the gait of great future beings that life carries ambitious and light yet towards new forms of adventure... A three-master of tender exhilaration, in route for Infinity...]

For Roquentin, however, the solipsistic desire eclipses all others, even though impossible to realize: "I want to leave, to go someplace where I would truly be in my place, where I would fit in... But my place is nowhere; I don't fit in" ["J'ai envie d'aller quelque part où je serais vraiment à ma place, où je m'emboîterais... Mais ma place est nulle part; je suis de trop"] (172). Thus, Roquentin remains frozen in time, sclerosed by existence, this "plenum that man cannot leave behind" ["ce plein que l'homme ne peut quitter"] (188), and ultimately obliged to reflect indefinitely upon this "ignoble marmelade" ["cette ignoble marmelade"] (189).

In conclusion, we can now see how Jean-Pierre Richard's patently Sartrean description of space in Voyage au bout de la nuit as a "molasses sky" over the "disgusting paste" of earth might in fact be more rhetorical flourish than useful criticism of the latter. ${ }^{11}$ Closer to the spirit of Céline's text - and to Merleau-Ponty's phenomenology - are his remarks on the novel's style. Here we find that Céline's discourse imitates "the movement of the inundation" while discouraging this "overflowing affectivity from carrying off the free cadences of language." 12 Since, according to Richard, "true style also impugns the excesses of nausea," the vitality of Céline's discourse must reside in "the vigor of this style [which], in the midst of turmoil and upheaval, aims to put us back on our feet again": Céline's style is thus endowed with a "salubriousness [...] in spite of its honest devotion to life's dark side."13 In a word, 
Bardamu's discourse conceals an essentially equivocal and ultimately irreducible character ${ }^{14}$ who ultimately abandons his journey to the end of the night with a final injunction of silence to the reader: "let us speak of it no more" ["qu'on n'en parle plus"] (636). In contrast, if for Roquentin "the world of explanations and reasons is not the world of existence" ["le monde des explications n'est pas celui de l'existence"] (182), he nonetheless persists in the belief that the "smile of the trees" ["le sourire des arbres"] in the public gardens means something in concealing from him "the true secret of existence" ["le véritable secret de l'existence"] (190). According to Merleau-Ponty, this persistence of affective memory is to be understood as the preponderance of psychological rationalism in the domain of anthropological space:

Si nous réfléchissons sur l'expérience mythique de l'espace et si nous nous demandons ce qu'elle veut dire, nous trouverons nécessairement qu'elle repose sur la conscience de l'espace objectif et unique, car un espace qui ne serait pas objectif et qui ne serait pas unique ne serait pas un espace: n'est-il pas essentiel à l'espace d'être le "dehors" absolu, corrélatif, mais aussi négation de la subjectivité, et ne lui est-il essentiel d'embrasser tout être qu'on puisse représenter, puisque tout ce qu'on voudrait poser hors de lui serait là même en rapport avec lui, donc en lui? (333-34)

[If we reflect on the mythical experience of space and if we ask ourselves what it means we will inevitably find that it rests on the consciousness of objective and unique space, for a space which is not objective and which is not unique is not a space: is it not essential that space should be the absolute "outside," correlative, but also the negation of subjectivity, and is it not essential for it to encompass all being which can be represented, since all one might wish to posit outside of it would be, by that very fact, in relation to it, and therefore within it?]

Thus, we can conclude by saying that the originality of La nausée stems in part from its unique reflection on the mythical experience of space which, through its incorporation in Sartre's ontological phenomenology, nonetheless purports to be universal. As for Voyage au bout de la nuit, let us say that its originality is derived from that property of mythical space which, following Merleau-Ponty, can be described as the original source of human experience. Or, as Céline himself aptly puts it: 
C'est bien agréable de toucher ce moment où la matière devient la vie. On monte jusqu'à la plaine infinie qui s'ouvre devant les hommes. (599)

[It is most pleasurable to reach that moment when matter becomes life. We rise up to the infinite plain which unfolds before men.]

\section{Notes}

${ }^{1}$ La Poétique de l'espace (Paris: PUF, 1958).

2 See for example Michel Beaujour, "Temps et substances dans Voyage au bout de la nuit" Cahier de l'Herne 3 (1963): 173-88. Beaujour concludes his essay with an insistence on Céline's stylistic genius which alone is able to transcend "a vomited and depreciated world" ["Le génie de Céline devient alors la seule transcendance face à un monde vomi et dévalorisé"] (188).

3 See for example Allen Thiher, Céline: The Novel as Delirium (Rutgers: Rutgers UP, 1972) in which nausea is described as a "visceral reaction induced by fear and disgust [...] and, as Sartre surely recognized, a way of entering into a new mode of perceiving the world" (25 [italics mine]).

4 All translations from the French are mine, as all page numbers refer to the French texts.

5 La Force de l'âge (Paris: Gallimard, 1960) 293.

6 See Goldthorpe 19: "The animistic imagery with which Roquentin posits his own thought as an object of affective reflection [1'objet psychique] is not, therefore, purely a literary device or an element of characterization; it constitutes, or gives rise to, an essential element of Sartre's thought, which he regards as being of universal validity."

${ }^{7}$ Schilling 57.

8 Schilling 58.

9 Schilling 58.

10 Schilling 74: "Dans le voyeurisme de Bardamu en revanche, nous constatons au sens plein du terme une volonté de participation. Écarté de tous par la fermeture de son espace polémique et rejeté dans la solitude par les comportements que cet héritage de guerre lui inspire, Bardamu essaie de revenir dans la société des hommes par le biais d'une 'curiosité' sans risques et n'impliquant pas de relations humaines directes." ["In Bardamu's voyeurism we ascertain in the full sense of the term a desire to participate. Distanced from others by the closed nature of his polemical space and cast into solitude by 
the behavior this legacy gives rise to, Bardamu attempts to come back among society by means of a risk-free 'curiosité' necessitating no direct human relations."]

11 Richard 27: “Un ciel-mélasse, [...] voilà la vraie définition célinienne de l'espace. J'ajoute que cette écoeurante pâte ne possède même pas les avantages de l'homogénéité."

12 Richard 41-43: "Car l'allure même du discours imite ici, et merveilleusement, les gestes de l'inondation [...] Mais il ne faut pas non plus qu'une affectivité débordante emporte les libres cadences du langage."

13 Richard 43: "Le vrai style récuse aussi les emportements de nausée [...] La vigueur de ce style vise, au sein des plus affreux effondrements, à nous remettre sur nos pieds, à nous rendre physiquement à nous-mêmes. D'où sa salubrité, et même, malgré son honnête dévotion à toutes les noirceurs de l'existence, son optimisme."

14 See Henri Godard, La poétique de Céline (Paris: Gallimard, 1985): 125-182, where precisely this aspect of Bardamu is directly linked to the plurivocalism of Céline's narrative style.

\section{Works Cited}

Céline, Louis-Ferdinand. Voyage au bout de la nuit. Paris: Gallimard, 1952.

Goldthorpe, Rhiannon. Sartre: Literature and Theory. Cambridge: Cambridge UP, 1984.

Merleau-Ponty, Maurice. Phénoménologie de la perception. Paris: Gallimard, 1945.

Richard, Jean-Pierre. Nausée de Céline. Fata Morgana, 1973.

Sartre, Jean-Paul. L'être et le néant: Essai d'ontologie phénoménologique. Paris: Gallimard, 1943.

—. La nausée. Paris: Gallimard, 1938.

Schilling, Gilbert. "Espace et angoisse dans Voyage au bout de la nuit." La Revue des lettres modernes 398-402 (1974): 57-80. 